\title{
TELAAH PEMIKIRAN HUKUM PROGRESIF UMAR BIN KHATAB PERSPEKTIF INDONESIA
}

\author{
Ridwan \\ Program Pascasarjana \\ Universitas Muhammadiyah Malang \\ gayokuridwan93@gmail.com
}

\begin{abstract}
Progressive law is a scientific endeavor that criticizes the conventional punishment of punishment by promoting formal legal truths, which is why law enforcement in this country can not bring happiness to seekers of justice. The progressive legal orientation is to ground the truth of justice, based on the premise that law is for man. The background of the birth of progressive legal thought is none other than due to the many problems that plagued law enforcement in Indonesia and never completed. The law must also be viewed from a social perspective, a behavior acceptable to and to the human being in it. The idea of progressive legal thought is interesting to discuss, examine and examine in depth. When viewed from the history of the development of Islamic law, it turns out that in the time of Caliph Umar ibn Khattab (634 to $644 A D$ ), he issued a lot of controversial ijtihad which visually contrary to the Qur'an or Hadith. The thoughts or the results of ijtihad Umar bin Khattab are also identical with the progressive law
\end{abstract}

\section{Keywords: Reasioning, Progressive Law, Umar bin Khattab}

\begin{abstract}
Abstrak, Hukum progresif merupakan ikhtiar ilmiah yang mengkritik cara berhukum konvensional yakni berhukum dengan mengedepankan kebenaran legal formal, yang menjadi sebab penegakan hukum di negeri ini tidak dapat memberi kebahagiaan kepada para pencari keadilan. Orientasi hukum progresif adalah membumikan sebenar keadilan, berpangkal pada pokok pikiran bahwa hukum adalah untuk manusia. Latar belakang lahirnya pemikiran hukum progresif tidak lain akibat banyaknya persoalan yang melanda penegakan hukum di Indonesia dan tidak pernah tuntas. Hukum juga harus dilihat dari perspektif sosial, perilaku yang dapat diterima oleh dan bagi insan yang ada di dalamnya. Gagasan pemikiran hukum progresif menarik untuk dibicarakan, ditelaah maupun dikaji secara mendalam. Bila dilihat dari sejarah perkembangan hukum Islam, temyata di zaman Khalifah Umar bin Khattab (634 s/d 644 M), beliau banyak mengeluarkan ijtihad yang kontroversial yang secara kasat mata bertentangan dengan Al-Qur'an ataupun Hadits. Pemikiran-pemikiran ataupun hasil ijthad Umar bin Khattab juga identik dengan hukum progresifnya.
\end{abstract}

Kata kunci: Pemikiran, Hukum Progresif, Umar Bin Khattab

\section{Pendahuluan}

Umar ibn al-Khaț̣āb (selanjutnya disebut "Umar) adalah salah seorang tokoh besar dalam sejarah perkembangan Islam. 'Umar adalah sahabat Rasulullah dan merupakan khalifah kedua setelah Abu Bakar. 'Umar memeluk Islam pada tahun ke-6 dari kenabian dalam usia 27 tahun dan merupakan satu dari sepuluh sahabat yang dijamin 
masuk surga ${ }^{1}$. Di masa kekhalifahannya, 'Umar tidak hanya berhasil melakukan perluasa daerah kekuasaan Islam, namun juga mampu menjalankan pemerintahanyang teratur, melalui kecerdasannya. 'Umar terkenal dalam menyumbangkan pemikiran yang cemerlang dalam perkembangan hukum Islam. Pemikiran-pemikiran 'Umar tertuang dalam ijtihadnyaz ${ }^{2}$. Hukum Progresif sendiri adalah hukum yang mampu mengikuti perkembangan zaman, mampu menjawab perubahan zaman dengan segala dasar di dalamnya, serta mampu melayani masyarakat dengan menyandarkan pada aspek moralitas dari sumber daya manusia penegak hukum itu sendiri. ${ }^{3}$

Keadilan merupakan sebuah tujuan (ghayah) dari suatu sistem peradilan. Dilihat dari akar katanya, keadilan berasal dari kata "adil" yang bermakna seimbang dan/atau proporsional. Pertama, seseorang disebut adil tatkala ia bisa memberikan hak kepada dua orang atau lebih secara merata (seimbang). Contoh sederhana, perlakuan orang tua terhadap kedua anak kembarnya dengan membelikan mainan yang sama. Kedua, seseorang juga dapat dikatakan adil ketika mampu memperlakukan setiap orang yang berinteraksi dengannya secara proporsional. Misalnya, sikap orang tua yang berbeda (proporsional) terhadap kedua anaknya, di mana anak pertama berumur 17 tahun dan anak kedua masih berumur 3 tahun. Dalam praktek peradilan di Indonesia, keadilan seringkali diukur berdasarkan penerapan peraturan perundang-undangan secara an-sich. Dengan kata lain, hakim yang memutuskan perkara sebagaimana yang ada di dalam undang-undang, maka putusannya dianggap sebagai putusan yang adil. Hukum hanya dimanifestasikan sebagai sebuah aturan yang rigid berupa undang-undang. Padahal, kenyataan membuktikan bahwa hukum tidak lahir dari ruang yang hampa, hukum tidak bisa menafikan kehadiran ilmu-ilmu non-hukum, seperti ilmu sosial, politik, agama dan semacamnya. Tanpa bantuan ilmu-ilmu non-hukum, praktik berhukum di negeri ini hanya akan melahirkan kesengsaraan bukan kesejahteraan. ${ }^{4}$

Negara Indonesia sebagai negara yang sedang berkembang tentunya sangat membutuhkan pembinaan dan pengembangan Sistem Hukum Nasional dalam rangka mendorong dan mendukung pembangunan di segala bidang. Meminjam istilah Roscoe Pound bahwa "as tool as social engineering", maka sesungguhnya pembinaan dan pengembangan hukum nasional sudah semestinya dapat memberikan arah dan jalan bagi hukum, masyarakat dan negara untuk saling terkait satu dengan yang lainnya. Tentunya hal itu dapat terwujud jika semangat dalam pembinaan dan pengembangan hukum nasional itu dilandasi dengan semangat dan nilai-nilai yang dianut dalam masyarakat dengan tidak mengenyampingkan juga nilai- nilai yang berkembang lainnya yang sesuai dengan kultur masyarakat Indonesia. ${ }^{5}$

Negara adalah merupakan organisasi kekuasaan yang nampaknya keluar terdiri dari aturan-aturan atau ketentuan-ketentuan hukum yang tersusun di dalam suatu tatanan

\footnotetext{
${ }^{1}$ alāl al-Dīn al-Suyūṭi, Tārīkh al-Khulafā' (Mesir: Maṭba 'ah Sa'ādah, 1952), hlm. 121.

${ }^{2}$ Secara sederhana ijtihad berarti mengerahkan kemampuan secara menyeluruh untuk menetapkan hukum-hukum syari at. Lihat: A. Hanafi, Ushul Fiqh (Jakarta: Wijaya, 1962), hlm. 151.

${ }^{3}$ Satjipto Rahardjo, Biarkan Hukum Mengalir (Jakarta: Kompas, 2007), hlm. ix.

${ }^{4}$ Malthuf Siroj dan Ismail Marzuki, Penegakan Hukum Progresif: Upaya Mewujudkan Keadilan Substantive, Jurnal HAKAM, Volume 1, Nomor 2, 2017. hlm. 1-2

5 Oksep Adhayanto, Perkembangan Sistem Hukum Nasional, Jurnal Ilmu Hukum, Volume 4, Nomor 2, Februari-Juli 2014. hlm. 4.
} 
hukum, oleh karena itulah seperti dikemukakan di atas, maka saat berdirinya negara akan bersamaan pula dengan saat berdirinya sistem hukum negara tersebut. ${ }^{6}$

Hal itu membuktikan mengapa, dengan lahirnya begitu banyak peraturan perundang-undangan yang sering kali secara diametral bertolak belakang nilai dan falsafahnya dengan peraturan hukum di Orde Baru, seluruh sistem hukum kita seakanakan tidak berfungsi atau seakan-akan "lumpuh". Hal ini disebabkan lembagalembaganya, struktur organisasinya, pejabat-pejabatnya, dan prosedur kerjanya, bahkan sering kali nilai-nilai yang dipegang teguh masih sama dengan di zaman orde baru, orde lama atau bahkan alam pikiran (minset) pejabat, hakim, atau masyarakat pengguna hukum masih tetap seperti di zaman kolonial, atau bahkan masih sama dengan di zaman sebelum kedatangan orang asing ke kepulauan Indonesia (hukum adat) ${ }^{7}$

Melihat wajah hukum Indonesia yang masih dibayang-bayangi dengan hukum kolonial memberikan kesan tersendiri bahwa hukum Indonesia tidak independen dikarenakan masih terinterdependensi dengan sistem hukum Belanda maupun sistem Hukum Prancis yang membentuk hukum Indonesia. Untuk itu, dalam rangka mewujudkan independensi atas hukum Indonesia, mau tidak mau pengembangan dan sistem hukum Indonesia mesti sesegera mungkin untuk dilaksanakan. ${ }^{8}$

Berdasarkan paparan di atas penulis tertarik untuk membahas lebih lanjut mengenai sejauh mana perspektif pemikiran 'Umar dengan konsep hukum Progresif yang diinisiasi oleh Satjipto Rahardjo. Tulisan ini sama sekali tidak bermaksud mengkritisi ataupun mengoreksi tulisan-tulisan yang lebih dahulu muncul, tetapi lebih penulis fokuskan pada bahasan menelaah Telaah Pemikiran Hukum Progresif Umar Bin Khatab Perspektif Indonesia.

\section{Pembahasan}

\section{Masa Pemerintahan Umar Bin Khattab}

Umar menjadi khalifah sebagai pengganti Abu Bakar tidak dihadapkan banyak sekali persoalan yang menantinya. Masalah perang dan perdamaian, banyak masyarakat yang membangkang membayar zakat, dan persoalan-persoalan sosial lainnya. ${ }^{9}$ Permasalahan-permasalahan yang timbul pada masa itu tidak lepas dari kemajemukan masyarakat bangsa Arab dan semakin luasnya daerah kekuasaan Islam.

Kehidupan ekonomi masyarakat Perekonomian masyarakat Arab pada masa sebelum Islam bias dibilang masih sederhana dan terbatas. Mayoritas aktivitas perekonomian pada saat itu adalah pada sektor pertanian, peternakan, dan perdagangan. Ketiga sektor ekonomi tersebut sangat berkaitan erat pada waktu itu. Para petani menggarap lahan pertanian mereka dengan menggunakan hewan-hewan ternak. Para pedagang juga menggunakan hewan-hewan ternak. ${ }^{10}$. Selain ketiga sektor tersebut, di

\footnotetext{
${ }^{6}$ Joeniarto, Sejarah Ketatanegaraan Republik Indonesia, (Bumi Aksara, Jakarta, 2001), hlm. 5

7 C.F.G Sunaryati Hartono, Bhinneka Tunggal Ika Sebagai Asas Hukum bagi Pembangunan Hukum Nasional, (Citra Aditya Bakti, Bandung, 2006), hlm. 45

${ }^{8}$ Ibid hlm. 6.

${ }^{9}$ Toha Husain, as-Syaikhan, Terj. Ali Audah, "Dua Tokoh Besar dalam Sejarah Islam; Abu Bakar dan Umar", (Jakarta: Dunia Pustaka Jaya, 1986), hlm. 141.

${ }^{10}$ Jaribah bin Ahmad al-Haritsi, Op.Cit, hlm. 31.
} 
negeri Arab juga terdapat ekonomi bidang industri. Akan tetapi sektor ini sangat lemah dan paling sedikit peranannya. Industri yang ada pada waktu itu mayoritas dijalankan oleh para budak dan orang-orang Yahudi. Diantaranya adalah industri besi, kayu, pertenunan, pembuatan senjata, dan lain-lain.

Bangsa Arab sebelum kedatangan Islam terkenal dengan akar budaya yang dalam sebagian berada dalam akhlak yang rusak. Mereka terkenal dengan sebutan jahiliyyah, karena kebodohan mereka akan akhlak-akhlak dan moral. Secara sosial, masyarakat Arab terdiri dari beberapa kelas dan tingkatan. Terdapat kelas masyarakat yang berada di posisi atas, yang dengan keberadaannya sebagai golongan atas mereka enggan bersama-sama dengan golongan yang ada di bawah mereka. Juga terdapat kelas masyarakat yang berada di tingkat bawah, rakyat jelata dan awam. Perbedaan tingkatan masyarakat menjadi sebuah hal yang wajar dalam masyarakat Arab. ${ }^{11}$

Masa pemerintahan Umar bin Khattab merupakan masa yang gemilang bagi perkembangan dan kemajuan agama Islam. Meskipun hanya menjabat khalifah selama kurang lebih sepuluh tahun, akan tetapi banyak sekali prestasi yang telah diraih pada masa itu. Prestasi yang dicapai meliputi banyak bidang, seperti dalam bidang perluasan wilayah, penataan administrasi negara, bidang perekonomian, keamanan dan ketertiban masyarakat, dan sebagai nya. Untuk mengungkapkan prestasi yang cemerlang dan sangat mengagumkan tersebut, bahkan ada yang mengatakan bahwa Umar bin Khattab adalah sebagai pendiri Negara Islam. ${ }^{12}$

Dalam masa pemerintahannya, Umar telah melakukan usaha-usaha yang memperkuat kedudukan agama Islam. Umar radhiyallahu'anhu juga dikatakan sebagai pelopor perundangundangan dalam negara Islam. membentuk badan-badan pemerintahan, dewan-dewan negara, mengatur peradilan dan administrasi, membentuk lembaga keuangan (bait al-mal), dan prestasi lainnya. ${ }^{13}$

\section{Pemikiran hukum progresif Umar Bin Khatab}

Sebagaimana diketahui bahwa Umar bin Khattab selaku Khalifah (pemegang tampuk pemerintahan) sifatnya keras, selalu berusaha bertindak adil dalam menegakkan hukum. la terkenal dan berani serta bijaksana dalam menerapkan ketentuan hukum yang terdapat dalam Al-Qur'an untuk mengatasi masalah yang timbul dalam masyarakat berdasarkan kemaslahatan atau kepentingan umum. Secara sepintas, keputusan (ijtihad) Umar bin Khattab seakan-akan bertentangan dengan ketentuan Al-Qur'an/Hadits, contohnya antara lain:

Secara sepintas, keputusan (ijtihad) Umar bin Khattab seakan-akan bertentangan dengan ketentuan Al-Qur'an/Hadits, contohnya antara lain:

1. Pada zaman Rasulullah maupun pada masa Khalifah Abu Bakar, talak 3 (tiga) dapat diucapkan sekaligus dan dianggap sebagai talak 1 (satu). Oleh Umar ditegaskan bahwa pengucapan talak tidak boleh langsung talak 3 tapi secara bertahap.

\footnotetext{
${ }^{11}$ Ibid, hlm. 33 .

12 Abbas Mahmud Al Akkad, Abqariyatu Umar, Terj.Gazirah Abdi Ummah "Kejeniusan Umar", (Jakarta: Pustaka Azzam, 2002), hlm. 95

${ }^{13}$ Ibid,96
} 
2. Al - Qur'an telah menetapkan golongan-golongan yang berhak menerima zakat, termasuk Muallaf di dalamnya (surah At - Taubah: 60). Oleh Umar, pemberian zakat kepada Muallaf dihentikan.

3. Al - Qur'an surah Al - Maidah ayat 38 menegaskan bahwa orang yang mencuri diancam dengan hukuman potong tangan, tetapi oleh Umar tidak dilaksanakan.

4. Umar melarang pria muslim menikahi wanita ahlul kitab, padahal Al-Qur'an Al Maidah ayat 5 membolehkan.

Jika disingkat pemikiran Umar ketika itu dan jangkauannya untuk masa kini dan ke depannya adalah

a. Talak 3 (tiga) yang diucapkan sekaligus di suatu tempat pada suatu ketika, dianggap sebagai talak yang tidak mungkin rujuk (kembali) sebagai suami istri, kecuali mantan istri kawin dahulu dengan orang lain, kemudian bercerai dan sudah habis masa iddahnya baru bisa kembali ke suami pertama dengan akad nikah yang baru. Garis hukum ini ditentukan oleh Umar berdasarkan kepentingan para wanita, karena dizamannya banyak suami yang dengan mudah mengucapkan talak 3 kepada istrinya untuk dapat bercerai dan kawin lagi dengan wanita lain. Tujuannya adalah untuk melindungi kaum wanita dari penyalahgunaan hak talak yang berada di tangan pria. ${ }^{14}$

Dengan demikian Tindakan Umar yang melarang suami menjatuhkan talak 3 sekaligus tanpa tahapan talak 1 maupun 2 terlebih dahulu, dimaksudkan agar suami berhati-hati mempergunakan hak talak itu dan sewenang-wenang mempergunakan hak nya. Secara yuridis maupun sosiologis, tindakan Umar seperti tesebut di atas sudah benar adanya karena di satu sisi beliau tetap menghargai dan menghormati hak talak yang ada pada suami dan di sisi lain penjatuhan talak tetap melindungi kaum istri

b. Memang benar golongan Muallaf termasuk golongan yang berhak menerima zakat, tetapi oleh Umar dihentikan. Pemikiran Umar yang menghentikan pemberian zakat untuk golongan Muallaf didasarkan pertimbangan bahwa Islam telah kuat, umat Islam telah banyak sehingga tidak perlu lagi diberikan keistimewaan kepada golongan khusus dalam tubuh umat Islam. ${ }^{15}$

\section{Sejarah Hukum Progresif Ala Indonesia}

Punggawa hukum progresif di Indonesia adalah Prof. Dr. Satjipto Rahardjo, SH. Beliau lahir di Banyumas Jawa Tengah pada tanggal 15 Desember 1930 dan wafat hari jum'at tanggal 08 Januari 2010. Maestro ilmu hukum Universitas Diponegoro (UNDIP) ini wafat diusia 79 tahun, setelah sebelumnya dirawat di Rumah Sakit Pusat PertamiZna (RSPP) Jakarta. ${ }^{16}$ Pemikiran hukum progresif lahir karena ada kekhawatiran terhadap

\footnotetext{
14 Mohammad Daud AM., Hukum Islam Pengantar llmu Hukum dan Tata Hukum Islam Di Indonesia, (Jakarta: Rajawali Pers, 1993), hlm. 157

${ }^{15}$ Ibid., hlm. 158

16 Suteki, "Rekam Jejak Pemikiran Hukum Progresif Prof. Dr. Satjipto Rahardjo, SH", http://mitrahukum.org/wp-content/uploads/2012/09/Rekam-Jejak-Pemikiran-Hukum-ProgresifProf-Satjipto-Rahardjo-by-Suteki.pdf , hlm. . 2, diunduh pada tanggal 05 Januari 2018
} 
kualitas penegakan hukum di Indonesia yang kurang memuaskan terutama sejak terjadinya reformasi sekitar tahun $1997 .{ }^{17}$

Sebagai pakar ilmu hukum yang memprakarsai pemikiran hukum progresif, Prof. Tjip (begitu orang-orang mengenalnya) menyadari bahwa wacana hukum progresif di Indonesia muncul sekitar tahun 2002. Inti dari pemikiran beliau adalah bagaimana memposisikan manusia secara sentral dalam hukum, karena menurut beliau hukum lahir untuk melayani manusia, bukan sebaliknya. ${ }^{18}$

Lebih jauh, dalam menelisik pemikiran hukum progresifsebenarnya mengingatkan kita pada sebagian pemikir ahli hukum terdahulu. Sebut saja Jeremy Bentham (1748-1832) tokoh terkemuka dari aliran/madzhab utilitarianisme, pokok pikiran aliran ini adalah "the aim of law is the greatest happiness for the greatest number of people", bahwa tujuan hukum adalah untuk mengupayakan kebahagiaan dan kemanfaatan bagi sebanyak-banyaknya manusia. Selain itu, terdapat juga tokoh aliran/madzhab sejarah (historis) bernama Friedrich Karl von Savigny yang dalam ajarannya mengatakan "das recht wird nicht gemacht, est ist und wird mit dem volke", bahwa hukum tidak dibuat tetapi tumbuh dan berkembang bersama masyarakat. ${ }^{19}$

Dengan demikian, lahirnya pemikiran hukum progresif dikarenakan hukum seringkali dijadikan sebagai bahan yang diperjual-belikan. Hukum dianggap sebagai barang yang bernilai ekonomis, sehingga banyak mafia peradilan mengkomersilkan hukum bagi para pencari keadilan. Akibatnya hukum seringkali diilustrasikan sebagai pisau dapur, yakni tajam ke bawah, namun tumpul ke atas. Akhirnya, hukum hanya bisa menjamin keadilan bagi siapa yang dapat menebusnya dengan materi.

Oleh karena itu pemikiran tokoh madzhab hukum di atas menyiratkan bahwa hukum seyogyanya meletakkan manusia sebagai sumber sentral untuk menggali dan mendapatkan nilai-nilai keadilan. Artinya, antara manusiadan hukum tidak boleh ada disintegrasi satu sama lain, melainkan keduanya merupakan satu-kesatuan yang tidak dapat dipisahkan. Maka oleh karena itu, diharapkan keadilan substantif dapat membumi di seluruh penjuru peradilan dan dapat dirasakan oleh setiap para pencari keadilan

\section{Landasan Konstitusional}

Tujuan berdirinya negara Indonesia di antaranya adalah untuk melindungi seluruh warga negara dari berbagai penindasan, kemiskinan, dan segala macam tindakan kesewenang-wenangan, mewujudkan kesejahteraan dan keadilan bagi seluruh rakyat Indonesia. Tujuan ini selaras dengan konstitusi bangsa Indonesia, yaitu dalam pembukaan Undang-Undang Dasar (UUD) 1945, utamanya alenia I dan IV, bahwa: Alenia I UUD 1945:"Bahwa sesungguhnya kemerdekaan itu ialah hak segala bangsa dan oleh sebab itu, maka penjajahan di atas dunia harus dihapuskan, karena tidak sesuai dengan perikemanusiaan dan peri-keadilan".

Alenia IV UUD 1945; "Kemudian dari pada itu untuk membentuk suatu Pemerintahan Negara Indonesia yang melindungi segenap bangsa Indonesia dan seluruh

\footnotetext{
${ }^{17}$ Vhttps://yuokysurinda.wordpress.com/2016/01/19/perkembangan-hukum-progresif/, Perkembangan Hukum Progresif di Indonesia, diunduh pada tanggal 05 Januari 2018.

${ }^{18}$ Ibid.

19 H. R. Otji Salman, Filsafat Hukum: Perkembangan \& Dinamika Masalah, (Bandung: PT. Refika Aditama, 2010), hlm. 44-45.
} 
tumpah darah Indonesia dan untuk memajukan kesejahteraan umum, mencerdaskan kehidupan bangsa, dan ikut melaksanakan ketertiban dunia yang berdasarkan kemerdekaan, perdamaian abadi dan keadilan sosial, maka disusunlah kemerdekaan kebangsaan Indonesia itu dalam suatu Undang- Undang Dasar Negara Indonesia, yang terbentuk dalam suatu susunan Negara Republik Indonesia yang berkedaulatan rakyat dengan berdasarkan kepada Ketuhanan yang Maha Esa, Kemanusiaan yang adil dan beradab, Persatuan Indonesia dan Kerakyatan yang dipimpin oleh hikmat kebijaksanaan dalam Permusyawaratan/perwakilan, serta dengan mewujudkan keadilan sosial bagi seluruh rakyat Indonesia.

Dari alenia I UUD 1945 di atas, secara tegas bangsa Indonesia menolak seluruh bentuk penjajahan karena sangat bertentangan dengan peri-kemanusiaan dan perikeadilan. Lebih jauh, konstitusi bangsa Indonesia menyatakan bahwa "kemerdekaan merupakan hak segala bangsa". Frase "kemerdekaan ialah hak segala bangsa" jika dipahami dengan baik akan mengarah pada suatu konsep bahwa upaya/akses untuk mencapai kesejahteraan, kemakmuran dan keadilan tidak hanya menjadi hak satu kelompok tertentu, melainkan menjadi hak seluruh bangsa Indonesia yang menempati wilayah nusantara ini. Untuk itu, penjaminan terhadap HAM dan keadilan yang berasaskan Pancasila untuk seluruh warga negara harus tercermin dalam berbagai bidang kehidupan, khususnya dalam konteks penegakan hukum di Indonesia. Maraknya peradilan yang tajam terhadap the poor (wong cilik) dan tumpul terhadap the have (orangorang besar), serta transaksi jual-beli pasal di antara para mafia peradilan, membuktikan bahwa sistem peradilan di negeri ini masih sangat suram. Oleh karena itu, sebagai suatu sistem, pembenahan di bidang hukum tidak selesai jika hanya memperbaiki substansi hukumnya (legal substance), sementara struktur hukum (legal structure) dan kultur hukumnya (legal culture) dibiarkan menjadi liar. ${ }^{20}$

Dengan demikian Prinsip-prinsip hukum progresif tersebut terlihat salah satunya dari gagasan utama hukum progresif yaitu menempatkan manusia sebagai sentralitas utama dari seluruh perbincangan mengenai hukum. Dengan kata lain, untuk mewujudkan konsep "hukum terbaik" tidak cukup dengan hanya memahami hukum sebagai peraturan perundang-undangan saja, tanpa berusaha memahami hukum sebagai perilaku manusia. Sebab, hakikatnya hukum tidak hanya berkaitan dengan undang-undang, tetapi juga perilaku manusia.

\section{Jalan Rekonseptualisasi}

Ada satu hal yang harus selalu diingat bahwa rule of law dan rechsstaat, memiliki akar konseptual dan konteks yang berbeda. Menurut Soetandyo, doktrin rechtsstaat masuk ke De Nederlands-Oost-Indie ketika diundangkan Reglement Op Het Beleid der

20 Substansi hukum adalah norma hukum, baik peraturan-peraturan, keputusan keputusan dan sebagainya yang semuanya itu dipergunakan oleh para penegak hukum maupun oleh mereka yang diatur. Sementara struktur hukum adalah kelembagaan yang diciptakan oleh sistem hukum seperti lembaga kepolisian, lembaga kejaksaan, dan sebagainya. Terakhir adalah kultur hukum yang merupakan ide-ide, sikap-sikap, harapan dan pendapat tentang hukum. Kultur hukum ini dibedakan menjadi 2, yakni internal legal culture (kultur hukumnya lawyers dan judged's) dan external legal culture (kultur hukumnya masyarakat pada umumnya). Lihat Esmi Warassih, Pranata Hukum: Sebuah Telaah Sosiologis, (Semarang: Badan Penerbit Universitas Diponegoro, 2011), hlm. 7 
Regering van Nederlands-Indie tahun 1854. Waktu itu, doktrin rechtsstaat sudah dipahami dalam konteks liberalisme Revolusi Perancis. Sedangkan ketika peralihan dari abad ke-20 menuju ke-21, Amerika menganut paham pragmatisme muncul aliran realisme hukum dalam sejarah hukum konsep rule of law telah terpahamkan dengan warna yang utilitarian dan mengejar kemanfaatan umum. ${ }^{21}$

Perspektif sejarah yang kuat untuk menjelaskan konteks politik hukum suatu doktrin atau ajaran tersebut menjadi penting. Lebih-lebih bila melengkapinya dengan sudut pandang bahwa hukum dan sistem hukum Indonesia tak bisa dilepaskan dari pengaruh kolonial yang cukup lama menguasai kelembagaan politik berikut dengan pengaruh kultural atas eksistensi dan bekerjanya hukum hingga saat ini. ${ }^{22}$

Ide negara hukum ingin menegaskan bahwa bahwa penentu dalam penyelenggaraan kekuasaan negara adalah hukum, yang prinsip-prinsipnya senantiasa berkembang sesuai perkembangan masyarakat. ${ }^{23}$

Dengan demikian Untuk mencari hukum Indonesia yang bisa memayungi berbagai kemungkinan hukum dalam satu ruang, penting dikaji bagaimana konseptualisasi dan perlukan rekonseptualitasi terhadap hukum tersebut. Hal ini penting untuk mendudukkan posisi hukum Indonesia dalam lalu lintas ilmu hukum.

Menurut Sunaryati Hartono. ${ }^{24}$ Rumusan Pembukaan UUD 1945, pendiri bangsa mencita-citakan agar Indonesia menjadi negara hukum yang demokratis, yang hukumnya wajib mengupayakan agar kesejahteraan umum dan kecerdasan bangsa. Melalui sila-sila dalam Pancasila tercermin falsafah negara hukum. Sila pertama terkait pengakuan eksistensi adanya bimbingan dan lindungan Tuhan Yang Maha Esa. Sila kedua menegaskan bahwa inti dari paham negara hukum dalam konteks Indonesia adalah berintikan keadilan. Sila ketiga terkait adanya pengakuan akan keberagaman. Sila keempat mengenai permusyawaratan. Sila kelima menegaskan posisi keadilan.

Selama ini praktek menjalankan negara hukum lebih banyak didominasi oleh kultur liberal. Paradigma legalisme liberal menghendaki agar menjalankan peraturan

21 Wiratraman, RHP., Dehumanisasi, Negara Hukum, dan Konstitusionalisme di Indonesia: Melacak Jejak Pemikiran Soetandyo Wignjosoebroto Soal Ketatanegaraan\|, dalam Safitri, MA (Ed.). Hukum yang Lahir dari Bumi Kultural Rakyat, Soetandyo Wignjosoebroto tentang Hukum, Sejarah, dan Keindonesiaan, (Jakarta: Epistema dan HuMA, 2015), hlm. 65. Lihat juga, Wignjosoebroto, S. 1994. Dari Hukum Kolonial ke Hukum Nasional: Suatu Kajian tentang Dinamika Sosial-Politik dalam Perkembangan Hukum Selama Satu Setengah Abad di Indonesia, (Jakarta: RajaGrafindo Persada, 1990), hlm. 457.

${ }^{22}$ Ibid

23 Jimly Asshiddiqie, Gagasan Dasar tentang Konstitusi dan Mahkamah Konstitusi, dalam Oktoberina, SR dan Savitri, N (Ed.), Butir-butir Pemikiran dalam Hukum Memperingati 70 Tahun Prof. Dr. B. Arief Sidharta, S.H., (Bandung: Refika Aditama2008), hlm. 204-205. Lihat juga, Jimly Asshiddiqie, Konstitusi dan Konstitualisme Indonesia. (Jakarta: Konstitusi Press, 2005), hlm. 152.

${ }^{24}$ Hartono S., Mencari Falsafah Hukum Indonesia yang Melatarbelakangi Pembukaan UndangUndang Dasar 1945\|, dalam Oktoberina, SR dan Savitri, N (Ed.), Butir-butir Pemikiran dalam Hukum Memperingati 70 Tahun Prof. Dr. B. Arief Sidharta, S.H. (Bandung: Refika Aditama, 2008), hlm. 151-155. 
sebagaimana adanya. Campur tangan akan menganggu pemuliaan terhadap kemerdekaan individu. $^{25}$

Mengikuti paham ini diakibatkan karena Indonesia lama dijajah oleh Belanda. Pada saat yang sama, akar budaya Indonesia adalah tidak tertulis. ${ }^{26}$. Negara hukum Indonesia diperoleh dari rechtsstaat dan rule of law. Bahkan Indonesia juga menerima nilai spiritual dari hukum agama Indonesia harus mengurai kembali watak negara hukum liberal. $^{27}$

\section{Konstruksi Baru Perilaku Etik Hakim Berbasis Hukum Progresif}

\begin{tabular}{|c|c|}
\hline Dimensi & Ciri-Ciri \\
\hline $\begin{array}{l}\text { Pandangan Dasar } \\
\text { Cara Berpikir } \\
\text { Cara Kerja } \\
\text { Kualifikasi } \\
\text { Pribadi } \\
\text { Orientasi Kerja }\end{array}$ & $\begin{array}{l}\text { - Hakim mempunyai pandangan bahwa hukum untuk manusia } \\
\text { bukan sebaliknya manusia untuk hukum } \\
\text { - Hakim mempunyai pandangan bahwa hukum bukan institusi } \\
\text { yang mutlak dan final, karena hukum selalu berada dalam } \\
\text { proses menjadi } \\
\text { - Hakim harus menolak status-quo manakala menimbulkan } \\
\text { dekadensi, suasana korup dan sangat merugikan kepentingan } \\
\text { rakyat } \\
\text { - Hakim harus memandang hukum tidak lepas dari relevansi } \\
\text { sosial; } \\
\text { - Hakim harus mempunyai spirit untuk membebaskan cara } \\
\text { berpikir hukum yang legal positivism } \\
\text { - Hakim harus peka terhadap perubahan yang terjadi di } \\
\text { masyarakat, baik lokal, nasional maupun global } \\
\text { - Hakim harus memaknai hukum secara kontekstual (progresif); } \\
\text { - Hakim harus bersikap imparsial (tidak memihak) dan hanya } \\
\text { memihak pada kebenaran } \\
\text { - Hakim harus dapat melakukan perubahan dengan melakukan } \\
\text { pemaknaan yang kreatif terhadap peraturan yang ada, tanpa } \\
\text { harus menunggu perubahan peraturan } \\
\text { - Peraturan yang buruk bukan menjadi penghalang bagi hakim } \\
\text { untuk menghadirkan keadilan bagi rakyat dan pencari keadilan; } \\
\text { - Hakim harus mempunyai multiple intellegence: kecerdasan } \\
\text { intelektual (IQ), emosional (EQ) dan spiritual (SQ) } \\
\text { - Hakim harus mempunyai kompetensi keilmuan dan kecakapan } \\
\text { profesional } \\
\text { - Hakim harus mempunyai kepribadian yang luhur dan } \\
\text { menjunjung tinggi moralitas } \\
\text { - Hakim harus mempunyai sifat-sifat sidiq (jujur), amanah (dapat } \\
\text { dipercaya), tabligh (terbuka) dan fatonah (cerdas); } \\
\text { - Hakim harus berorientasi untuk mewujudkan hukum yang adil }\end{array}$ \\
\hline
\end{tabular}

${ }^{25}$ Rahardjo, S., Hukum dalam Jagad Ketertiban, (Jakarta: UKI Press, 2006), hlm.119. Bandingkan Kusumaatmaja, M. Konsep-konsep Hukum dalam Pembangunan Kumpulan Karya Tulis. Cetakan Kedua. (Bandung: Alumni, 2006), hlm. 33-34.

${ }^{26}$ Mahfud MD., Inilah Hukum Progresif Indonesia, dalam Mahfud MD dkk. 2013. Dekonstruksi dan Gerakan Pemikiran Hukum Progresif. (Yogyakarta: Thafa Media, 2013) hlm. 9-11.

${ }^{27}$ Muntoha. Demokrasi dan Negara Hukum, Jurnal Hukum. 16 (3): 2009, 379-395. 


\begin{tabular}{|l|l|}
\hline & $\begin{array}{l}\text { secara subtantif dan bukan sebatas keadilan prosedural (idealis) } \\
\text { Hakim tidak berperilaku materialis dan pragmatis dalam } \\
\text { menjalankan profesi. }\end{array}$ \\
\hline
\end{tabular}

\section{Hukum Progresif Memandang bahwa Hukum Untuk Manusia}

Kekeliruan paradigma ilmu hukum positivistik terletak pada pemahaman objek studinya yang membatasi hukum hanya pada perundang-undangan semata. Maka wajar jika seseorang yang belajar ilmu hukum hanya mampu mengoperasikan/menjalankan hukum sebagaimana ia menjalankan kendaraan. Padahal ilmu hukum jika ditinjau secara holistik tidak hanya berkaitan dengan peraturan perundang-undangan, tetapi lebih jauh, ilmu hukum juga berkaitan dengan lingkungan, alam dan manusia, bahkan orde kehidupan yang lebih besar. ${ }^{29}$.

Hukum progresif merupakan gagasan ilmu hukum yang mengalir,tidak mau terjebak dalam status quo, yang pada akhirnya menyebabkan ia menjadi stagnan. Lebih dari itu, hukum progresif ingin selalu setia pada asas besar bahwa "hukum itu untuk manusia, bukan sebaliknya. ${ }^{30}$

\section{Penutup}

Berdasarkan uraian di atas dapat ditarik beberapa kesimpulan sebagai berikut:

1. Umar di dalam penegakan hukum tidak terbelenggu dengan teks tapi keluar dan teks demi kepentingan masyarakat umum

2. Pada masa khalifah Umar bin Khattab, beliau sudah berani dengan keyakinannya sendiri untuk menegakkan hukum dengan mengutamakan nilai keadilan.

3. Hal ini antara lain terjadi karena tekanan melalui industrialiasasi dan globalisasi yang menyebabkan terjadinya modernisasi hukum. Umar terlebih dahulu mempertimbangkan kasus-kasus serupa pada masa Rasulullah beserta metode penyelesaiannya dalam konteks sosial historis. Dengan kata lain, 'Umar menggunakan metode penarikan keputusan berdasarkan kesamaan kondisi yang dikenal dengan istilah qiyās. Kedua, Hukum progresif yang dipopulerkan oleh Satjipto Rahardjo memiliki paradigma bahwa hukum sepenuhnya untuk manusia dan menolak untuk mempertahankan status quo dalam berhukum. Selain itu hukum progresif memberikan perhatian besar terhadap peranan perilaku manusia dalam hukum. Ketiga, ijtihad 'Umar ibn al-Khațāa dan hukum Progresif memiliki beberapa kesamaan karakteristik, yaitu sama-sama menyatakan bahwa hukum hadir untuk kebaikan manusia.

Kemudian Pengembangan hukum nasional Indonesia merupakan suatu hal yang mau tidak mau mesti dilakukan oleh pemerintah dalam rangka membentuk hukum nasional yang mengakar ke seluruh lapisan masyarakat. Pengembangan hukum nasional

${ }^{28}$ M. Syamsudin, Rekonstruksi Perilaku Etik Hakim Dalam Menangani Perkara Berbasis Hukum Progresif, Jurnal Hukum No. Edisi Khusus Vol. 18 Oktober 2011, hlm. 127

29 Satjipto Rahadjo, Hukum Progresif: Hukum Yang Membebaskan, dalam Jurnal Hukum Progresif, Vol. 1 No.1, Tahun 2005, hlm. . 35.

30 Dey Ravena, Mencandra Hukum Progresif dan Peran Penegakan Hukum di Indonesia, Syiar Hukum, Vol 9, No 3 (2007), hlm. 191 
Indonesia yang saat ini sangat dipengaruhi oleh unsur-unsur luar sedapat mungkin untuk tetap mempertahankan sumber-sumber hukum materil dari hukum-hukum Indonesia.

Di negara Indonesia berangkat dari konsep rechtsstaat, yang dipengaruhi juga oleh rule of law. Keduanya sudah disadari pengaruh sejak ketika pembahasan UUD dilakukan oleh BPUPKI Tahun 1945. Dari awal, pendiri bangsa sudah mempersiapkan sejumlah dasar pijakan yang kini dapat ditemui dalam nilai Pancasila. Kedua, dalam perkembangannya, pengaruh Barat juga tidak mungkin diketam, antara lain terjadi melalui transplantasi baik struktur maupun ide.

\section{Daftar pustaka}

Abbas Mahmud Al Akkad, Abqariyatu Umar, Terj.Gazirah Abdi Ummah "Kejeniusan Umar", Jakarta: Pustaka Azzam, 2002

Al-Suyūțī, Jalāl al-Dīn, Tārīkh al-Khulafā', Mesir: Maṭba 'ah Sa 'ādah, 1952

Asshiddiqie, (Ed.). J. -Gagasan Dasar tentang Konstitusi dan Mahkamah Konstitusill, 2008

C.F.G Sunaryati Hartono, Bhinneka Tunggal Ika Sebagai Asas Hukum bagi Pembangunan Hukum Nasional, Citra Aditya Bakti, Bandung, 2006

Esmi Warassih, Pranata Hukum: Sebuah Telaah Sosiologis, Semarang: Badan Penerbit Universitas Diponegoro, 2011

Hanafi, A., Ushul Fiqh, Jakarta: Wijaya, 1962.

Hartono, S. -Mencari Falsafah Hukum Indonesia yang Melatarbelakangi Pembukaan Undang-Undang Dasar 1945, 2008

Joeniarto, Sejarah Ketatanegaraan Republik Indonesia, Bumi Aksara, Jakarta, 2001

M. Syamsudin, Jurnal Hukum No. Edisi Khusus Vol. 18 Oktober 2011127 - 145 Rekonstruksi Perilaku Etik Hakim Dalam Menangani Perkara Berbasis Hukum Progresif, 2011.

Mahfud MD. -Inilah Hukum Progresif Indonesiall, Dekonstruksi dan Gerakan Pemikiran Hukum Progresif. Yogyakarta: Thafa Media, 2013.

Mohammad Daud AM, Hukum Islam Pengantar llmu Hukum dan Tata Hukum Islam Di Indonesia. Jakarta: Rajawali Pers, 1993

Malthuf Siroj dan Ismail, Jurnal HAKAM Marzuki penegakan hukum progresif: upaya mewujudkan keadilan substantive, 2017

Muntoha, Demokrasi dan Negara Hukum. Jurnal Hukum, 2009

Oksep adhayanto, perkembangan sistem hukum nasional jurnal jurnal ilmu hukum volume 4 no. 2 februari-juli 2014 
Otji Salman H. R., Filsafat Hukum: Perkembangan \& Dinamika Masalah, Bandung: PT. Refika Aditama, 2010

Perkembangan Hukum Progresif di Indonesia, diunduh pada tanggal 05 Januari 2018.

Rahardjo, S. Hukum dalam Jagad Ketertiban. Jakarta: UKI Press. 2006

Rahardjo, Satjipto, Biarkan Hukum Mengalir, Jakarta: Kompas, 2007

Safitri, MA (Ed.) Hukum yang Lahir dari Bumi Kultural Rakyat, Soetandyo Wignjosoebroto tentang Hukum, Sejarah, dan Keindonesiaan. Jakarta: Epistema dan HuMA, 2015

Satjipto Rahadjo, Hukum Progresif: Hukum Yang Membebaskan, dalam Jurnal Hukum Progresif, Vol. 1 No.1, Tahun 2005

Surinda,Vhttps://yuokysurinda.wordpress.com/2016/01/19/perkembangan-hukumprogresif/, Suteki, "Rekam Jejak Pemikiran Hukum Progresif Prof. Dr. Satjipto Rahardjo, SH”, hal. 2, artikel yang diunduh pada tanggal 05 Januari 2018

Toha Husain, as-Syaikhan, Terj. Ali Audah "Dua Tokoh Besar dalam Sejarah Islam; Abu Bakar dan Umar", Jakarta: Dunia Pustaka Jaya, 1986 